\title{
EVIDENCE OF PARTHENOGENETIC POPULATIONS FROM THE Paratanytarsus laccophilus species group (Diptera: Chironomidae) in the Alaskan Arctic
}

\author{
Alec R. Lackmann ${ }^{1,2}$, Daniel C. McEwen ${ }^{3}$, Malcolm G. Butler ${ }^{4}$ \\ ${ }^{1}$ University of Minnesota Duluth, Department of Biology, 1035 Kirby Drive, SSB 207, Duluth, MN 55812. \\ ${ }^{2}$ North Dakota State University, Department of Biological Sciences, Environmental and Conservation Sci- \\ ences Program, PO Box 6050, Fargo, North Dakota, USA 58108.E-mail: alackman@d.umn.edu \\ ${ }^{3}$ Limnopro Aquatic Science, Inc. PO Box 764, St. Cloud, MN 56302.E-mail: dan@limnopro.com \\ ${ }^{4}$ North Dakota State University, Department of Biological Sciences, Fargo, North Dakota, USA. \\ E-mail: malcolm.butler@ndsu.edu
}

\begin{abstract}
Parthenogenesis, reproduction without fertilization, is not common in the Chironomidae (Diptera), a family of insects with more than 6,000 described species. Nonetheless, parthenogenetic species and strains have been documented in at least three subfamilies (the Chironominae, Orthocladiinae, and Telmatogoninae), spanning 17 genera and $\sim 30$ species. One such species, Paratanytarsus laccophilus Edwards 1929, is known to be parthenogenetic in a small portion of its range in Finland, with most other European populations of this species showing evidence of sexual reproduction. We present evidence of parthenogenetic populations from the Paratanytarsus laccophilus species group in the Nearctic, specifically a High Arctic site near Utqiagivik (formerly Barrow), Alaska. During May-July of 2015 and 2016, we sampled emerging adult chironomids and pupal exuviae daily to document insect emergence phenologies. Across 15 local populations, all 623 pupal exuviae collected from the $P$. laccophilus species group were female. Larvae reared from two populations under controlled temperature treatments emerged as female adults $(\mathrm{N}=37)$. When isolated, these reared female adults oviposited, and eggs hatched successfully. These progeny were reared for another 12-13 days, reaching second instar larvae when they were preserved at the end of our field season. Taken together, this evidence strongly indicates parthenogenesis from the $P$. laccophilus species group at this location. This species was not previously documented at Utqiagivik. Although parthenogenetic, their emergence at this location was highly synchronized. In the harsh environment of arctic Alaska, the fitness rewards of parthenogenesis are likely great. Indeed, chironomid parthenogenesis in the northern hemisphere is most commonly documented from far-northern extremes and in extreme habitats.
\end{abstract}

\section{Introduction}

While sexual reproduction is widespread in the animal kingdom, parthenogenesis is a widespread form of asexual reproduction in which there is no fertilization of the egg (Suomalainen 1962; Lynch 1984). Parthenogenesis in animals evolves most commonly as an artifact of hybridization (Carew et al. 2013) and is most often thelytokous, i.e. where all asexually produced offspring are female. Because offspring are genetically monotonous with mutation as the only source of variation (Lynch 1984), parthenogenesis is often considered an evolutionary dead end (Darlington 1946; Mayr 1970; Smith 1978). Nonetheless, patterns exist in the distribution of parthenogenetic forms that suggest this reproductive strategy could be evolutionarily advantageous in certain cases.

"Geographic parthenogenesis" describes the observation that parthenogenesis tends to evolve in habitats that are different from where their closely related, sexually-reproducing relatives reside (Vandel 1928). Indeed, parthenogenetic species are most commonly documented from high latitudes, especially in harsh habitat conditions (Lynch 1984). Proposals articulated to account for this phenomenon include the "biotic-uncertainty" hypothesis (Ghiselin 1974), and the "tangled bank" hypothesis (Bell 1982). The biotic-uncertainty hypothesis postulates that parthenogens tend to persist in harsh environments that are relatively barren biologically, and an environment with minimal biotic interaction favors the persistence of genetically monotonous lineages. The tangled bank hypothesis argues that harsh environments are less niche-specialized because they are frequently disturbed. This selects against genetically diverse progeny pre-adapted to fill a diverse array of niches, providing opportunities for clonal populations. These rather intuitive hypotheses include many assumptions, remain untested, and are unsatisfactory in explaining geographic parthenogenesis (Lynch 1984). 
Although parthenogenesis is rather widespread across some insect groups such as the Hymenoptera (Suomalainen 1962), it is relatively uncommon in the Chironomidae (Lindeberg 1951; Armitage et al. 1995; Gokhman and Kuznetsova 2017). These non-biting midge flies are often the most common and species-rich macroinvertebrate taxon in freshwater habitats, with estimates of the total richness of this family surpassing 10,000 species (Armitage et al. 1995), with the tropics still poorly studied (Ferrington 2007).
Of the at least 6,434 described chironomid species to date (ISC 2017; Stur and Ekrem 2020), less than $0.5 \%$ ( $\sim 30$ species $)$ are known as parthenogens (Table 1). These represent 3 of the 11 extant chironomid subfamilies (Cranston et al. 2012): the Chironominae, Orthocladiinae, and Telmatogoninae. In the Chironominae, there are 17 parthenogenetic species found among 7 genera (Grimm 1870; Thienemann 1954; Lindeberg 1958; Lindeberg 1971; Grodhaus 1971; Oliver and Danks 1972; Armitage et al. 1995; Langton 1998; Donato and Paggi 2008; Porter and Martin 2011); in the

Table 1. Chironomid taxa with evidence of parthenogenesis as of 2020.

\begin{tabular}{|c|c|c|}
\hline Subfamily & Taxon & Reference \\
\hline \multirow[t]{17}{*}{ Chironominae } & Tanytarsus norvegicus (Kieffer, 1924) & Lindeberg 1971 \\
\hline & Tanytarsus gregarius (Kieffer, 1909) & Lindeberg 1971 \\
\hline & Tanytarsus sp. (sylvaticus) & Lindeberg 1971 \\
\hline & Tanytarsus sp. (lestagei) & Lindeberg 1971 \\
\hline & Tanytarsus heliomesonyctios (Langton, 1999) & Langton 1998 \\
\hline & Paratanytarsus grimmii (Schneider, 1885) & Grimm 1870 \\
\hline & Paratanytarsus laccophilus (Edwards, 1929) & Lindeberg 1958 \\
\hline & Paratanytarsus sp. (boiemicus) & Lindeberg 1971 \\
\hline & Micropsectra silvesterae (Langton, 1999) & Langton 1998 \\
\hline & Micropsectra sp. (nigripila) & Armitage et al. 1995 \\
\hline & Micropsectra sedna (Oliver, 1976) & Porter et al. 2011 \\
\hline & Chironomus atrella (Townes, 1945) & Grodhaus 1971 \\
\hline & Chironomus attenuatus (Walker, 1848) & Grodhaus 1971 \\
\hline & Chironomus stigmaterus (Say, 1823) & Grodhaus 1971 \\
\hline & Lauterborniella sp. & Oliver et al. 1972 \\
\hline & Polypedilum parthenogeneticum (Donato and Paggi, 2008) & Donato et al. 2008 \\
\hline & Zavreliella marmorata (Wulp, 1858) & Thienemann 1954 \\
\hline \multirow[t]{12}{*}{ Orthocladiinae } & Corynoneura celeripes (Winnertz, 1852) & Edwards 1919 \\
\hline & Corynoneura donovani (Forsyth, 1971) & Forsyth 1971 \\
\hline & Corynoneura scutellata (Winnertz, 1846) & Edward et al. 1968 \\
\hline & Limnophyes minimus (Meigen, 1818) & Armitage et al. 1995 \\
\hline & Limnophyes vestitus (Skuse, 1889) & Forsyth 1971 \\
\hline & Abiskomyia virgo (Edwards, 1937) & Armitage et al. 1995 \\
\hline & Bryophaenocladius furcatus (Kieffer, 1916) & Armitage et al. 1995 \\
\hline & Eretmoptera murphyi (Schaeffer, 1914) & Armitage et al. 1995 \\
\hline & Metriocnemus abdominoflavatus (Picado, 1913) & Thienemann 1954 \\
\hline & Phytotelmatocladius delarosai (Epler, 2010) & Siri et al. 2014 \\
\hline & Pseudosmittia baueri (Strenzke, 1960) & Armitage et al. 1995 \\
\hline & Troglocladius hajdi (Andersen, Baranov et Hagenlund, 2016) & Andersen et al. 2016 \\
\hline \multirow[t]{2}{*}{ Telmatogetoninae } & Telmatogeton amphibious (Eaton, 1875) & Crafford 1971 \\
\hline & Telmatogeton sp. & Delettre et al. 2003 \\
\hline
\end{tabular}


Orthocladiinae there are 12 species from 9 genera (Edwards 1919; Thienemann 1954; Edward and Colless 1968; Forsyth 1971; Armitage et al. 1995; Siri and Donato 2014; Andersen et al. 2016; Bartlett et al. 2018); and in the Telmatogetoninae there are two species from the type genus Telmatogeton (Crafford 1971; Delettre et al. 2003).

Of all these parthenogenetic species (Table 1), the best represented genera are Tanytarsus, Paratanytarsus, Micropsectra, Corynoneura, and Limnophyes, while at the other extreme some genera show very limited evidence of parthenogenesis (e.g. Chironomus) (Oliver and Danks 1972; Armitage et al. 1995). Although most parthenogenetic chironomids are found in arctic and subarctic habitats (Armitage et al. 1995), others are reported from sub-Antarctic islands (Crafford 1971; Delettre et al. 2003), phytotelmata in Argentina (Siri et al. 2014), and a cave in Croatia (Andersen et al. 2016). Furthermore, since many of these parthenogenetic chironomids are triploid and of hybrid origin, they are permanent genetic heterozygotes that may be more apt to find certain habitats suitable (Carew et al. 2013). Considering the wide range of habitats and the taxonomic difficulty of identifying female midges, parthenogenesis in the Chironomidae may be more common than previously believed (Ekrem et al. 2010; Stur and Ekrem 2020).

Not only do parthenogenetic chironomids vary in habitat, but they also vary in the extent of their parthenogenesis. Some of the taxa in Table 1 are strictly parthenogenetic, like Paratanytarsus grimmii, the globally-distributed, notorious pest of water-supply systems (Carew et al. 2013). Other taxa (e.g. Tanytarsus heliomesonyctios) exhibit population-specific parthenogenesis, with parthenogenesis evident for populations that occur in relatively harsh environmental conditions (Orel and Semenchenko 2019; Stur and Ekrem 2020). This is also the case for Paratanytarsus laccophilus. Lindeberg $(1958,1971)$ documented parthenogenetic populations of $P$. laccophilus in rock pools on the isles of the Gulf of Finland, yet found bisexual reproduction in all other locations where he studied this species. Here we present evidence of additional parthenogenetic populations from the P. laccophilus species group, found in the North American High Arctic near Utqiagivik, Alaska.

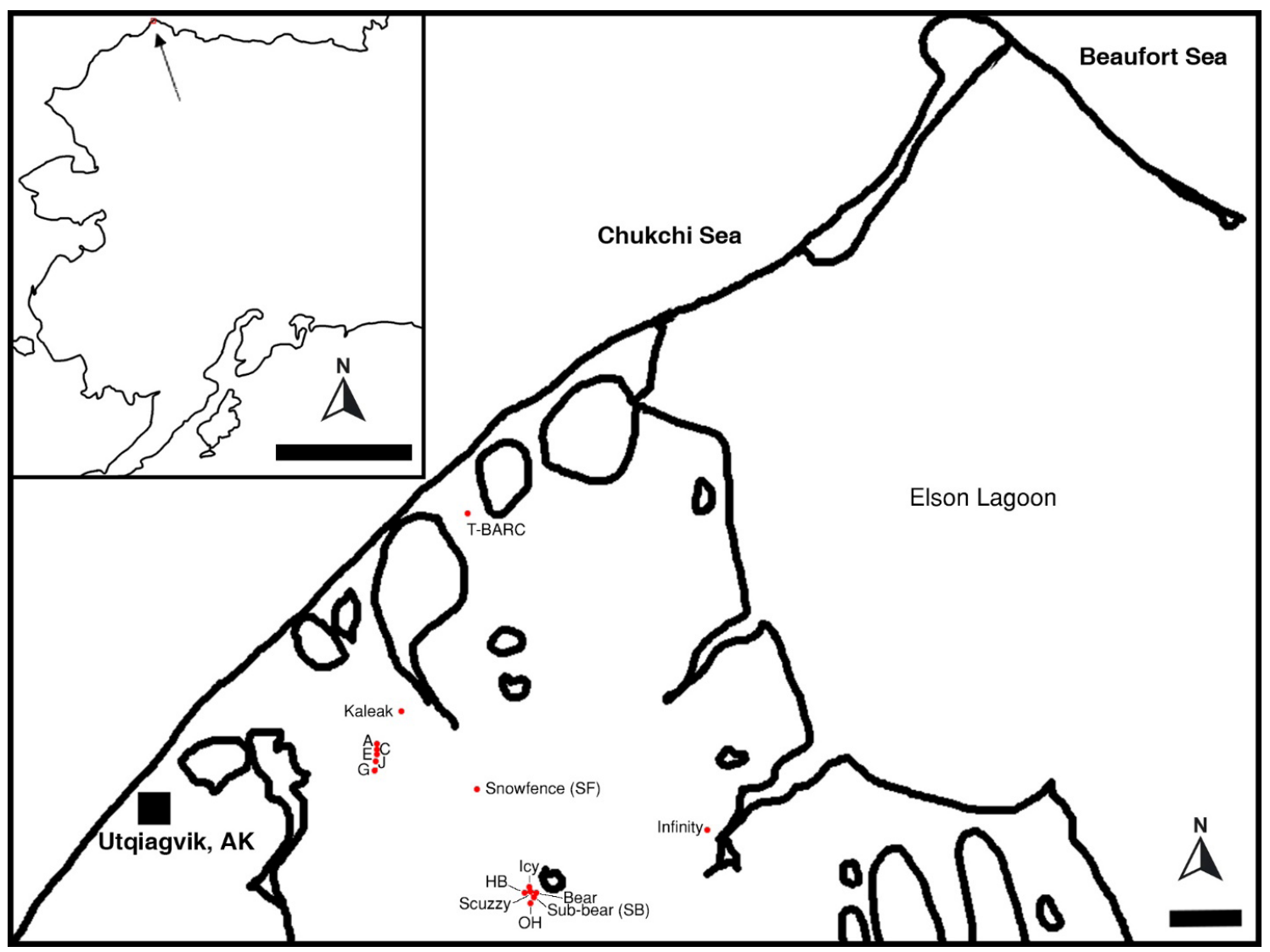

Figure 1. Map of the field site at Utqiagvik, Alaska. Individuals of the Paratanytarsus laccophilus species group were taken from the fifteen tundra ponds labeled (red dots). Scale bars $=500 \mathrm{~km}$ (inset), and $1 \mathrm{~km}$. 


\section{Materials and Methods}

The study site is located at Utqiagivik (formerly Barrow), Alaska $\left(71^{\circ} 17^{\prime} 27.5^{\prime \prime} \mathrm{N} 156^{\circ} 47^{\prime} 18.5^{\prime \prime} \mathrm{W}\right)$. We sampled a total of fourteen tundra ponds (Fig. 1) within an $8 \mathrm{~km}$ radius of the village for chironomid pupal exuviae (PEs) across the 2015 and 2016 emergence seasons (i.e. from thaw in midlate May to late July, when chironomid emergence ended). We conducted this phenological sampling daily in both years, with Ponds A, C, E, J, G, and Kaleak sampled on even days, while Ponds Bear, $\mathrm{OH}, \mathrm{HB}$, Icy, and Sub-Bear sampled on odd days. Ponds Snowfence and Scuzzy were part of the odd day sampling in 2015 only, and Pond Infinity was sampled only twice in 2015.

Ponds A, C, E, J, G, OH, Bear, and Infinity are low-centered polygon ponds (Liljedahl et al. 2012) with a maximum depth of $0.5 \mathrm{~m}$, surface areas largely consisting of open water, and ranging in size from $\sim 175 \mathrm{~m}^{2}$ to $900 \mathrm{~m}^{2}$ total area. Ponds HB and Icy are degrading ice-wedge ponds (Liljedahl et al. 2012) with a maximum depth of $2 \mathrm{~m}$, largely open water, and size ranging from $\sim 120 \mathrm{~m}^{2}$ to 180 $\mathrm{m}^{2}$ total area. Ponds Kaleak, Snowfence, Sub-Bear, and Scuzzy are the smallest ponds (areas $\sim 18 \mathrm{~m}^{2}$ to $750 \mathrm{~m}^{2)}$ and shallowest (maximum depth $\sim 30 \mathrm{~cm}$ ) and are thoroughly vegetated with Carex and Arctophila. Sub-Bear, and Scuzzy are so shallow they lost most standing water by late June).

Samples consisted of five $1 \mathrm{~m}$ dip net sweeps taken on the downwind side of the pond to collect surface-floating PEs and emerging or failed adults. Pooled net contents were stored in $35 \%$ ethanol in the field, and subsequently transferred to $70 \%$ ethanol. Sampled PEs were sorted, sexed, and tallied in the lab under a dissecting microscope, and identified to species group according to Wiederholm (1986).

While processing 2015 field samples, it became evident that individuals of the $P$. laccophilus species group might be parthenogenetic due to a lack of males. In 2016 we took larval samples for rearing under controlled temperature conditions in the lab. These larvae came from Kaleak Pond on 19 and 28 June, and from Pond T-BARC (Fig. 1) on 30 June. Small tanytarsine larvae hypothesized to include individuals of the $P$. laccophilus species group were batch-placed into rearing cups (replicated thrice) with detritus and pond water and incubated at eight temperature treatments ranging from $5-25^{\circ} \mathrm{C}$ (as this rearing setup was part of another study testing chironomid developmental responses to temperature). These lab incubations consisted of eight oxygenated aquaria controlled for water tem- perature $\left( \pm 1^{\circ} \mathrm{C}\right)$ with EcoPlus ${ }^{\mathrm{TM}}$ aquarium chillers and monitored with Onset ${ }^{\circledR}$ Hoboware temperature loggers. We monitored larvae and pupae daily for development and emergence of adult flies. For each emerged specimen, we recorded temperature treatment, source pond, species, sex (confirmed by examination of PE genital structures under a dissecting microscope), and date of eclosion. We immediately preserved emerged adults and their pupal exuviae (PEs) in $70 \%$ EtOH, except when an emerged singleton from the $P$. laccophilus species group was confirmed (see below). Adults were photographed laterally under a Wild dissecting microscope (Fig. 2) in a thin film of $70 \% \mathrm{EtOH}$ - just enough to submerse the specimen such that individuals would lie laterally. Photomicroscopy was done with a Canon EOS Rebel T3i camera attached to a trinocular mount.

We isolated reared singletons of the P. laccophilus species group that were confirmed as virgin (i.e. no other species or conspecifics had emerged in that daily cohort) by first locating the adult midge beneath the mesh of the rearing cup by shining a light through the base of the cup (Fig. 3a). When a potential specimen was located, we carefully coaxed her to the mesh of the lid (were she not already there). As adults of this species are fast and agile fliers, we took care to prevent escapees. Once the female was on the mesh, (Fig. 3a), we carefully unscrewed the lid and quickly placed it on the table, trapping the fly. We then located and identified the lone PE within the opened rearing cup to confirm it was of the $P$. laccophilus species group (Fig. 3b). If confirmed, we prepared a new rearing cup containing only pond water. The lid with the trapped female clinging to the mesh was then quickly transferred to the new rearing cup. We monitored these isolated individuals for behavior, and ultimately, oviposition. If oviposition took place, we monitored and photographed the egg mass daily under a dissecting microscope, watching for egg development and hatching. Once hatched and larvulae had consumed the gelatinous mass surrounding the eggs, we added filtered (50 $\mu \mathrm{m}$ ) pond detritus (free of exotic chironomid larvae) to each microcosm.

We used JMP 14 Pro Statistical Discovery ${ }^{\mathrm{TM}}$ for statistical analysis and graphical output. Degree hours $(\mathrm{DH})$ for each emerged specimen were calculated as mean temperature experienced*total hours for development.

\section{Results}

Over the 2015 and 2016 field seasons, we collected a total of 623 PEs of the P. laccophilus species 


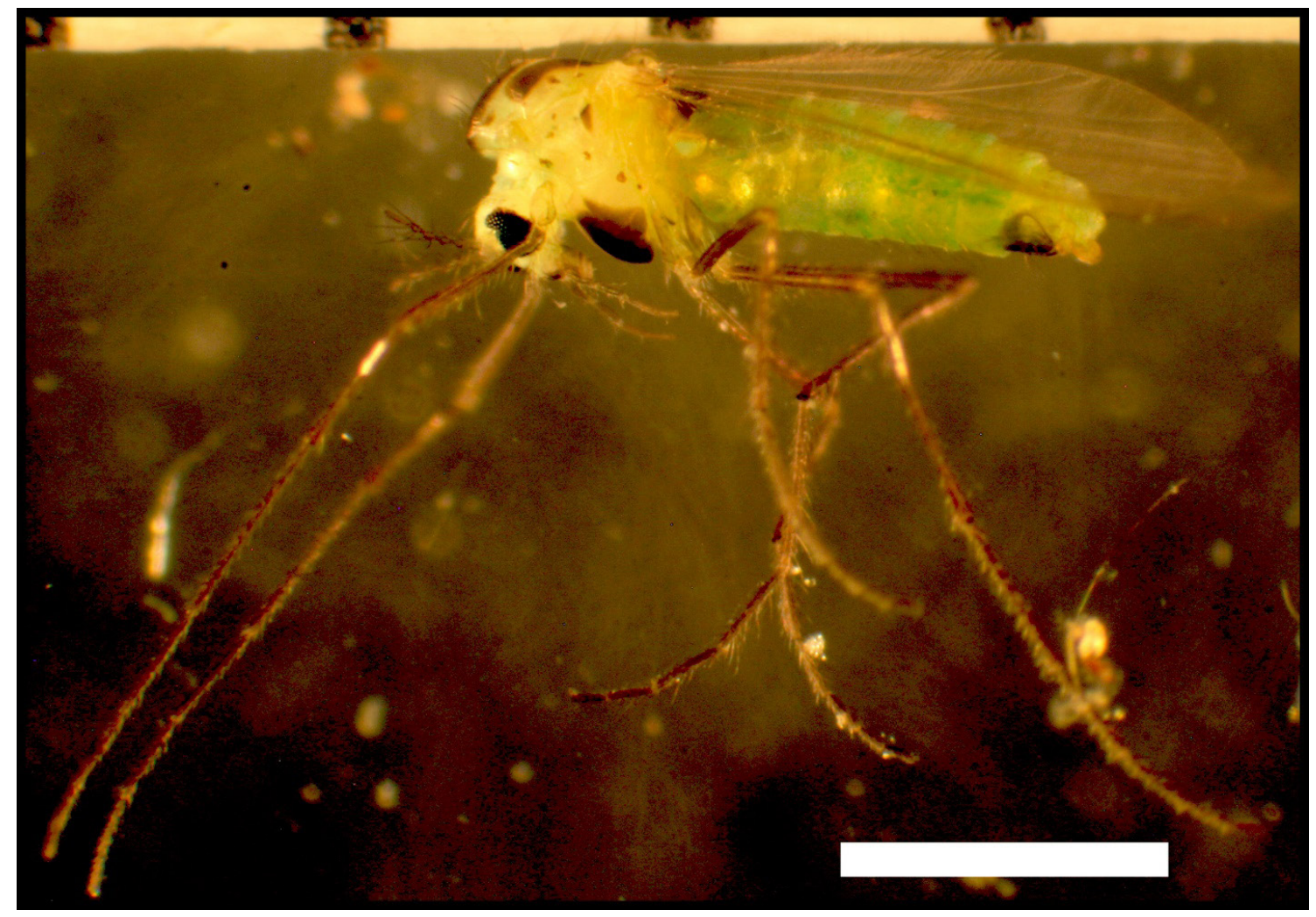

Figure 2. Lateral view of a recently emerged individual (female) of the Paratanytarsus laccophilus species group in Utqiagvik, Alaska. The specimen was submerged in a thin film of $70 \% \mathrm{EtOH}$ immediately after it emerged from a rearing cup in the lab, and her natural coloration was captured via photomicroscopy. Scale bar $=1 \mathrm{~mm}$.

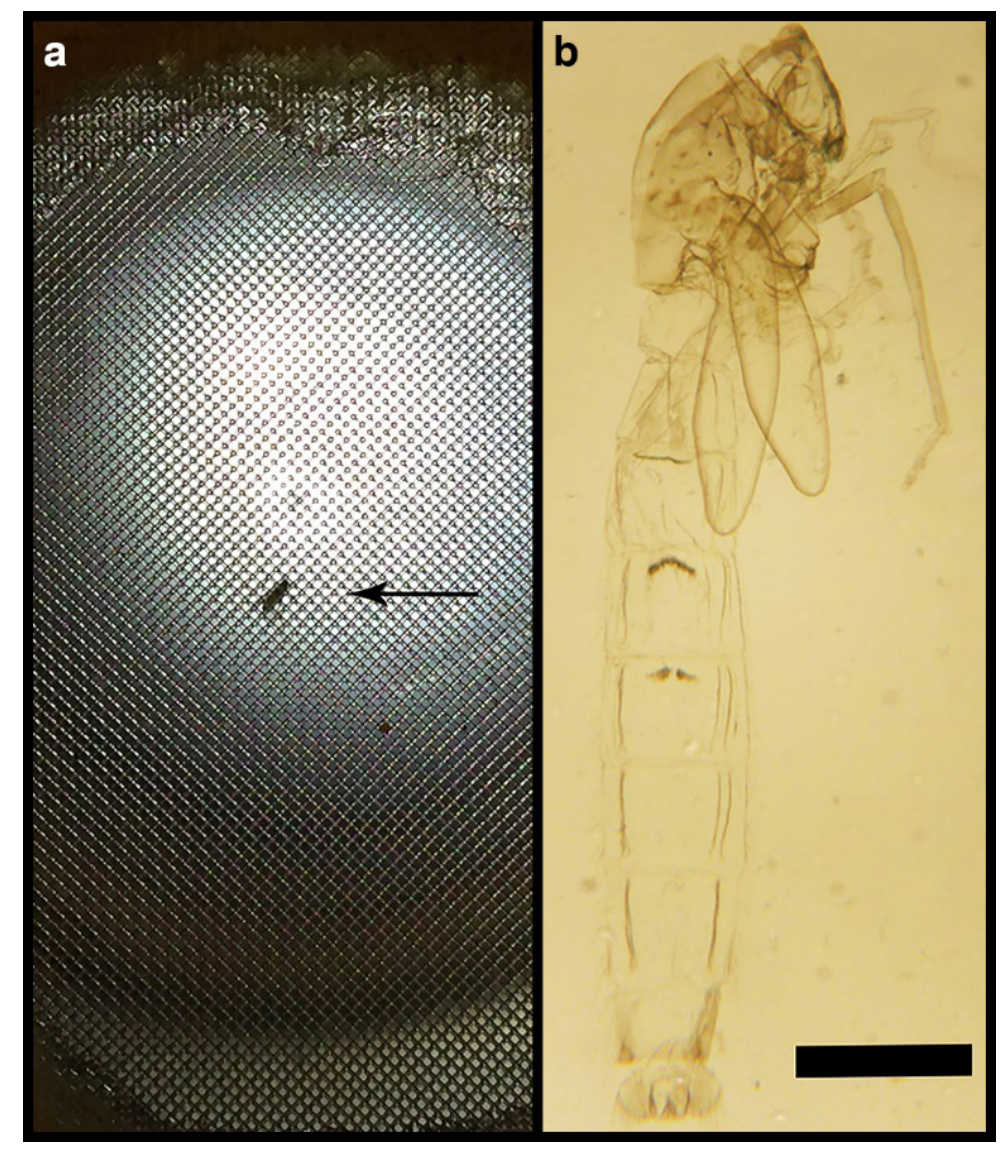

Figure 3. a) A freshly emerged, virgin individual of the Paratanytarsus laccophilus species group (arrow) clinging to the mesh lid of the new rearing cup to which it was transferred. The isolated female was then monitored daily for signs of oviposition. b) The pupal exuviae (PE) collected from the larval rearing cup, used to confirm species-group identification. Note the diagnostic patterning on abdominal tergites III and IV (Wiederholm 1986). Scale bar in $(b)=0.5 \mathrm{~mm}$. 
group, identified according to Wiederholm (1986). All specimens were female, and came from fourteen tundra ponds (Fig. 1) representing a range of habitat types (see methods). We also reared 37 individuals of the $P$. laccophilus species group (all female), from larvae, collected from two pond sources, to emergence under lab conditions (Table 2).

Kaleak Pond produced the most specimens of the $P$. laccophilus species group of all habitats across both years, and the PE sweep data from this pond offers insight into the species' emergence phenology (Fig. 4). This species showed highly synchronized emergence, even compared to other, sexually-reproducing species at Utqiagivik (Butler 1980a). In 2015, the peak emergence date (the date on which the greatest number of this species emerged for a given year) for individuals of the $P$. laccophilus species group (Julian date 170) was also the first day PEs of this species were collected from this pond, and these comprised $76 \%(139 / 183)$ of that season's total. Our 2015 sampling in Kaleak began 20 days earlier (on Julian date 150: 30 May), and no PEs of this species were collected on any of the 13 day-specific samples prior to peak emergence on Julian date 170 (19 June). In 2016, 72\% $(242 / 338)$ of all collected individuals of this species emerged in three consecutive samples from 4-8 July (Julian dates 186, 188, and 190), with the peak for this year being 8 July (Fig. 4a), again documenting a high degree of emergence synchrony.
In 2015 and 2016 the median date of emergence was also the date of peak emergence in both years (Julian dates 170 and 190 respectively).

Despite this synchrony, this species' emergence timing varied across years. Thaw dates were nearly identical in Kaleak Pond between 2015 and 2016, with only a two-day difference - 2015 having the later start (Fig. 4b). Yet peak emergence of this species in 2015 was $\sim 20$ days earlier than in 2016 (Fig. 4a). This difference in phenological emergence pulse corresponds to a difference of more than 3,800 DH between the two years. In 2015, the median degree hour experience from thaw to emergence was 4,102 (mean: 5,339 \pm 378 [95\% CI]), while in 2016 it was 7,986 (mean: 8,026 \pm $132[95 \% \mathrm{CI}])$. Comparing median values, the $\mathrm{DH}$ experienced from thaw to emergence in 2015 was just $51 \%$ of that experienced in 2016 .

Of the 37 individual larvae reared adults (all were female) in the lab, three emerged as singletons. These were transferred into their own rearing cups and tracked for behavior and oviposition. These adult females were most often seen clinging to the mesh lid (Fig. 3a), but were sometimes observed skittering across, or resting on the water's surface in the rearing cup. We found one adult "belly-up" on the surface of the water three days after she eclosed and was moved to her isolated cup (Table $3)$. The adult was confirmed dead, and no signs of progeny were discovered in the rearing cup (e.g. no egg mass or larvae).

Table 2. Collection information for individuals of the Paratanytarsus laccophilus species group in the present study.

\begin{tabular}{|c|c|c|c|c|c|}
\hline $\mathrm{N}(2015,2016)$ & $\mathrm{N}$ (total) & $\%$ ㅇ & Pond & Coordinates & Sample type \\
\hline$(183,338)$ & 521 & 100 & Kaleak & $71^{\circ} 17^{\prime} 54.36^{\prime \prime} \mathrm{N}, 156^{\circ} 41^{\prime} 46.32^{\prime \prime} \mathrm{W}$ & PE sweep \\
\hline$(36, \mathrm{NA})$ & 36 & 100 & Snowfence & $71^{\circ} 17^{\prime} 23.52^{\prime \prime} \mathrm{N}, 156^{\circ} 39^{\prime} 45.09^{\prime \prime} \mathrm{W}$ & PE sweep \\
\hline$(1,12)$ & 13 & 100 & Icy & $71^{\circ} 16^{\prime} 39.46^{\prime \prime} \mathrm{N}, 156^{\circ} 38^{\prime} 31.29^{\prime \prime} \mathrm{W}$ & PE sweep \\
\hline$(4,3)$ & 7 & 100 & $\mathrm{~J}$ & $71^{\circ} 17^{\prime} 36.75^{\prime \prime} \mathrm{N}, 156^{\circ} 42^{\prime} 5.43^{\prime \prime} \mathrm{W}$ & PE sweep \\
\hline$(2,5)$ & 7 & 100 & G & $71^{\circ} 17^{\prime} 32.84^{\prime \prime} \mathrm{N}, 156^{\circ} 42^{\prime} 3.55^{\prime \prime} \mathrm{W}$ & PE sweep \\
\hline$(2,4)$ & 6 & 100 & Sub-bear & $71^{\circ} 16^{\prime} 36.36^{\prime \prime} \mathrm{N}, 156^{\circ} 38^{\prime} 24.19^{\prime \prime} \mathrm{W}$ & PE sweep \\
\hline$(3,2)$ & 5 & 100 & A & $71^{\circ} 17^{\prime} 41.33^{\prime \prime} \mathrm{N}, 156^{\circ} 42^{\prime} 9.39^{\prime \prime} \mathrm{W}$ & PE sweep \\
\hline$(1,4)$ & 5 & 100 & $\mathrm{HB}$ & $71^{\circ} 16^{\prime} 38.42^{\prime \prime} \mathrm{N}, 156^{\circ} 38^{\prime} 32.46^{\prime \prime} \mathrm{W}$ & PE sweep \\
\hline$(5, \mathrm{NA})$ & 5 & 100 & Scuzzy & $71^{\circ} 16^{\prime} 38.72^{\prime \prime} \mathrm{N}, 156^{\circ} 38^{\prime} 31.49^{\prime \prime} \mathrm{W}$ & PE sweep \\
\hline$(0,5)$ & 5 & 100 & Bear & $71^{\circ} 16^{\prime} 37.11^{\prime \prime} \mathrm{N}, 156^{\circ} 38^{\prime} 22.99^{\prime \prime} \mathrm{W}$ & PE sweep \\
\hline$(4, \mathrm{NA})$ & 4 & 100 & Infinity & $71^{\circ} 17^{\prime} 4.26^{\prime \prime} \mathrm{N}, 156^{\circ} 34^{\prime} 22.65^{\prime \prime} \mathrm{W}$ & PE sweep \\
\hline$(1,2)$ & 3 & 100 & $\mathrm{C}$ & $71^{\circ} 17^{\prime} 40.21^{\prime \prime} \mathrm{N}, 156^{\circ} 42^{\prime} 8.06^{\prime \prime} \mathrm{W}$ & PE sweep \\
\hline$(1,2)$ & 3 & 100 & $\mathrm{E}$ & $71^{\circ} 17^{\prime} 38.85^{\prime \prime} \mathrm{N}, 156^{\circ} 42^{\prime} 6.81^{\prime \prime} \mathrm{W}$ & PE sweep \\
\hline$(1,2)$ & 3 & 100 & $\mathrm{OH}$ & $71^{\circ} 16^{\prime} 35.25^{\prime \prime} \mathrm{N}, 156^{\circ} 38^{\prime} 27.91^{\prime \prime} \mathrm{W}$ & PE sweep \\
\hline (NA, 34) & 34 & 100 & Kaleak & $71^{\circ} 17^{\prime} 54.36^{\prime \prime} \mathrm{N}, 156^{\circ} 41^{\prime} 46.32^{\prime \prime} \mathrm{W}$ & Lab rearing \\
\hline$(\mathrm{NA}, 3)$ & 3 & 100 & T-BARC & $71^{\circ} 19^{\prime} 25.18^{\prime \prime} \mathrm{N}, 156^{\circ} 40^{\prime} 7.30^{\prime \prime} \mathrm{W}$ & Lab rearing \\
\hline $\mathrm{N}(\mathrm{All})$ & 660 & 100 & 15 & NA & \\
\hline
\end{tabular}




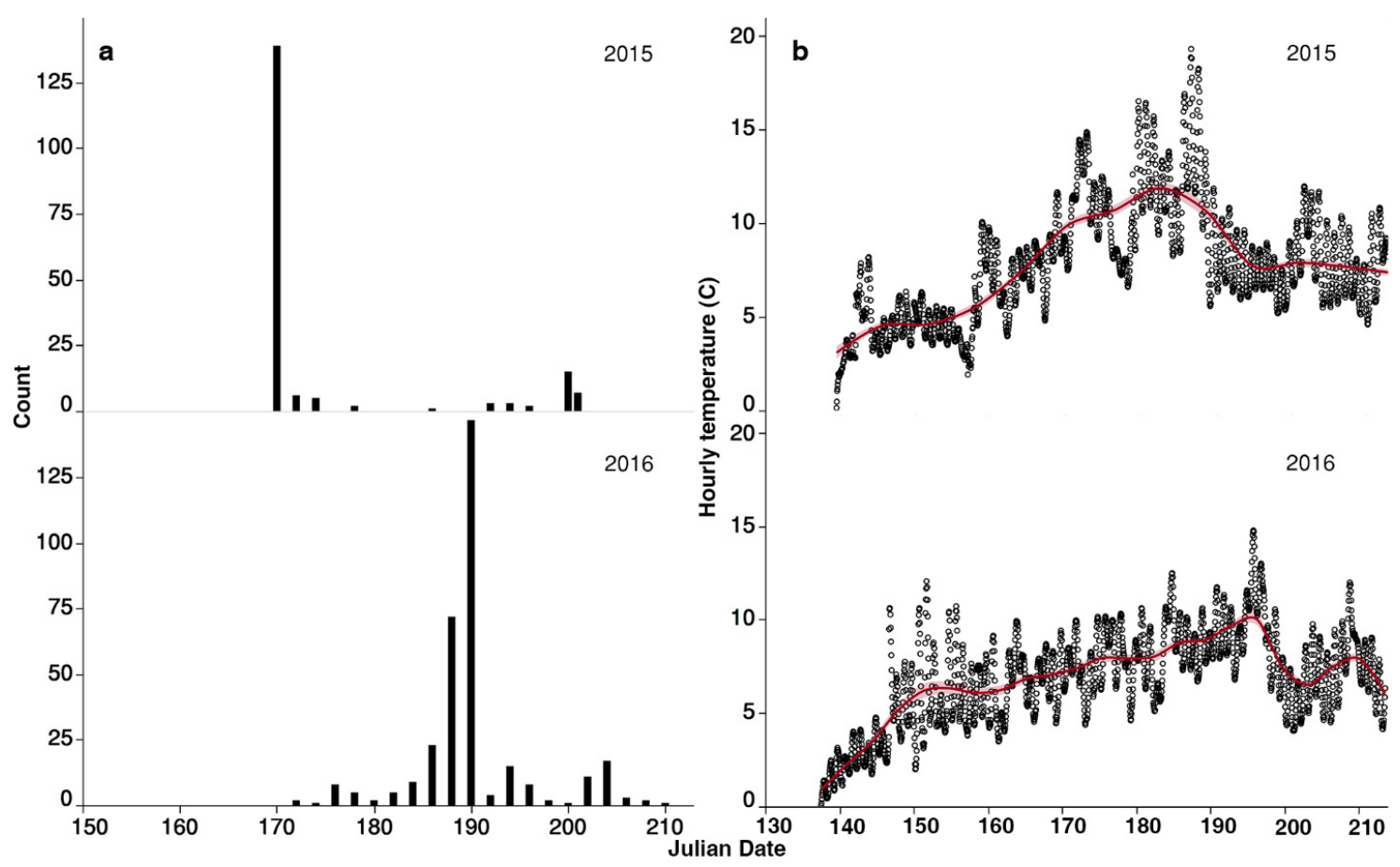

Figure 4. a) Emergence synchrony of individuals of the Paratanytarsus laccophilus species group as evidenced by pupal exuviae count vs. sample date (Julian) in 2015 and 2016 from Kaleak Pond. In both years sampling began on Julian day 150 (30 May and 29 May, respectively). In 2015 sampling concluded on Julian date 201 (20 July), and in 2016 on day 213 (31 July). b) Hourly temperature $\left({ }^{\circ} \mathrm{C}\right)$ vs. Julian date from a Hoboware data logger in Kaleak Pond. Thaw was defined according to McEwen and Butler (2018) using the pond-specific logger. In 2015 pond thaw occurred on day 139 (19 May), and in 2016 on day 137 (16 May). The red curve through the data points represents the cubic spline with a bootstrap confidence region at lambda $=0.05$.

The other adults died 2-3 days after eclosion. Upon inspection, a single egg mass was immediately noticeable in the bottom of each cup (Fig. 5a-b). These egg masses consisted of a string of eggs in a spiral, within an outer, oval-shaped, gelatinous mass. After 2-5 days (depending on treatment) the eggs hatched (Fig. $5 \mathrm{c}-\mathrm{g}$ ). Larvulae remained within the spiral of the egg rope (e.g. Fig. $5 \mathrm{~g}$ ) in the hours immediately after hatch. By the next day they were moving within the outer gelatinous matrix of the egg mass or freely moving about the rearing cup. The egg mass morphology, time between eclosion and deposition of the egg mass, egg number, time to hatch, and larvulae behavior are all concordant with Lindeberg's (1958) pioneering work describing parthenogenetic populations of $P$. laccophilus in southern Finland.
After we added pond detritus to the rearing cups, the newly hatched larvulae grew and developed in their respective temperature treatments for the remaining duration of the field season. As this species emerged rather late in the season (Fig. 4a) compared to known chironomid phenologies at Utqiagivik (Butler 1980a; Butler 1982; Braegelman 2016; Lackmann and Butler 2018; Butler and Braegelman 2018), there was little time for additional larval development as our field season ended on 31 July. We preserved the thriving larvae on 28 July and found numerous larval exuviae (LEs) in each rearing cup, indicating that these parthenogenetically-produced larvae had molted to the second larval instar.

Table 3. Individual adults from the Paratanytarsus laccophilus species group reared in isolation and their subsequent life history events. All three individuals came from Kaleak Pond. Individual (I); Temperature treatment (Trt); Larval exuviae (LEs)

\begin{tabular}{llllllll}
\hline I & Trt. $\left({ }^{\circ} \mathrm{C}\right)$ & Eclosion & Oviposit & Adult perished & \# of eggs & Hatch & LEs present \\
\hline 1 & 18.3 & 2 July & NA & 5 July & NA & NA & NA \\
2 & 15.3 & 8 July & 11 July & 11 July & 109 & 16 July & 28 July \\
3 & 21.0 & 11 July & 13 July & 13 July & 87 & 15 July & 28 July \\
\hline
\end{tabular}




\section{Discussion}

In cases like Paratanytarsus laccophilus, where parthenogenesis appears population-specific, it remains unclear if populations are facultatively parthenogenetic in certain environments, or if obligatory bisexual and asexual strains have evolved independently and now coexist globally (Lindeberg 1971; Oliver and Danks 1972; Armitage et al. 1995). No matter how it evolved, parthenogenesis in a chironomid at Utqiagivik, AK should not be surprising. The study site is located in the High Arctic where temperatures are low, winds are high, and the overwintering period encompasses most of the year (Butler 1980a). The fitness benefits of being parthenogenetic in such a habitat are likely great because every individual in the population is female and is theoretically capable of producing offspring herself. The risk involved in finding a mate is avoided, and only one individual is hypothetically necessary to establish a population in a new habitat (Lynch 1984). This allows for rapid population growth and productivity. Sexually reproducing species tend to require more individuals for population establishment to be successful, because future generations may be unlikely to find mates if founding numbers are low (Suomalainen 1962; Lynch 1984; Bartlett et al. 2018; 2020).

It is unknown when individuals of the Paratanytarsus laccophilus species group colonized Utqiagivik. Similar to what has been completed for Paratanytarsus grimmii (Carew et al. 2013), genetic analyses on populations of $P$. laccophilus at a global scale (e.g. from Finland and Alaska) would be valuable in understanding this history, and in determining the exact taxonomic position of these Alaskan populations. Such genetic information could provide insight on the dispersal of $P$. laccophilus over evolutionary time and provide a basis for interpreting the species' present trajectory. It is interesting to note that this species group was not documented in the Utqiagivik chironomid fauna during the 1970s (Lougheed et al. 2011), and that the habitats where this species was most abundant in the present study (thoroughly-vegetated, shallow tundra ponds) have also increased substantially over this timeframe (Liljedahl et al. 2016). The species may simply have gone undetected during the 1970s because their habitat type was not as frequently sampled as it was in the 2010s. It is also possible that this parthenogenetic species is a recent invader of this polar extreme, similar to the parthenogenetic chironomid Eretmoptera murphyi that recently invaded Antarctica (Bartlett et al. 2018; 2020), but this remains unknown.

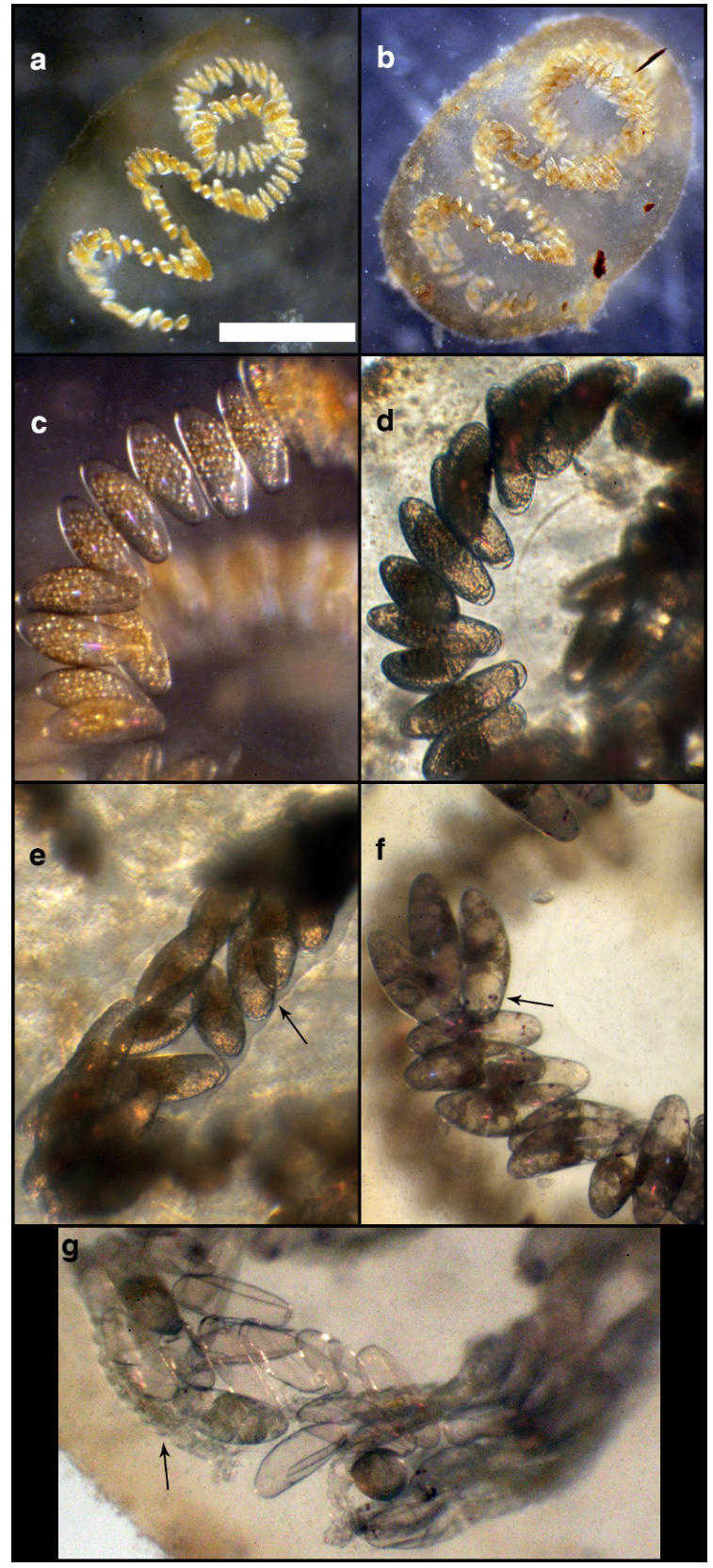

Figure 5. Development of parthenogenetic Paratanytarsus laccophilus species-group progeny in the $15.3{ }^{\circ} \mathrm{C}$ treatment in 2016. a) An egg mass freshly laid on 11 July. b) The same egg mass on 15 July, just before hatch. c-g) Daily progression of development. c) Eggs on 12 July 2016 at one day old. d) At two days old. e) At three days old, eye spots (arrow) and head capsules were evident inside the egg. f) At four days old, eye spots and head capsules (arrow) were well-defined within the egg. g) Larvulae (arrow) hatched on 16 July, five days after oviposition. Several vacated eggs are clearly notable. Scale bar $=1 \mathrm{~mm}$ for $\mathrm{a}$ and $\mathrm{b}$, and 250 $\mu \mathrm{m}$ for c-g. 
The highly synchronous emergence of this Alaskan population is intriguing considering males are lacking and females reproduce parthenogenetically. Thus, selection for synchronized emergence for the purpose of mate-finding, as proposed by Butler (1980a), would seem unnecessary. Perhaps their synchronized emergence is a heritage trait from sexually reproducing ancestors. Still, other factors (e.g. optimal temperatures and polarized light) might maintain such eclosion synchrony, even as there is continuous light during the arctic growing season, but this remains to be studied. In contrast, the parthenogenetic and brachypterous E. murhpyi that has invaded Antarctica ecloses asynchronously across a broad phenology (2-3 months) (Bartlett et al. 2018; 2020).

Even though individuals of the P. laccophilus species group emerged highly synchronously (i.e. $>70 \%$ of total emergence occurred within a 4-day interval in both years), their seasonal timing and total heat sum from spring thaw to eclosion differed substantially (Fig. 4). This may suggest that larvae overwinter at different stages of development on a year-to-year basis depending on how much they can develop prior to the fall freeze, or that other environmental variables, that have so far gone unstudied, are significant drivers of their emergence timing. In the current climate change era, arctic warming is amplified (IPCC 2014). If individuals of the $P$. laccophilus species group colonized the Alaskan Arctic with the past 50 years, perhaps they are pre-adapted for this rapidly evolving tundra landscape. Migratory shorebirds are also well-documented to feed on chironomids at this location (Braegelman 2016). If these populations thrive under such a warming climate and evolving landscape, it might benefit some avian insectivores.

\section{Conclusion}

We present evidence of parthenogenesis in an arctic Alaskan chironomid of the Paratanytarsus laccophilus species group. This evidence suggests a reevaluation of geographic parthenogenesis in $P$. laccophilus is necessary. It may turn out that Lindeberg's original hypothesis of geographic parthenogenesis in this species is correct (1958), even though he later discarded it (1971). Although parthenogenesis in the Chironomidae is generally considered uncommon (Armitage et al. 1995), population-specific incidences such as $P$. laccophilus suggest other sexually reproducing species may have parthenogenetic strains that are not yet known.

\section{Acknowledgements}

This work was completed at North Dakota State University (NDSU), USA as part of a doctoral dissertation by ARL. The North Slope Borough and the Ukpeagvik Inupiat Corporation permitted access to the field site. We thank Ewelina BielakLackmann and Kevin Cortes for assistance in the field and lab, and Dr. Shane D. Braegelman for helpful discussion and advice. We gratefully acknowledge financial support from the U.S. Arctic Landscape Conservation Cooperative, the U.S. National Fish and Wildlife Foundation, and the Environmental and Conservation Sciences Program at NDSU.

\section{References}

Andersen, T., Baranov, V., Hagenlund, L.K., Ivković, M., Kvifte, G.M., and Pavlek, M. 2016. Blind flight? A new troglobiotic Orthoclad (Diptera, Chironomidae) from the Lukina Jama-Trojama Cave in Croatia. - PloS One 11(4): e0152884. DOI: https://doi.org/10.1371/ journal.pone.0152884

Armitage, P.D., Cranston, P.S. and Pinder, L.C.V. 1995. The Chironomidae. The biology and ecology of non-biting midges. Chapman \& Hall, 572 p.

Baek, M.J., Yoon, T.J., and Bae, Y.J. 2012. Development of Glyptotendipes tokunagai (Diptera: Chironomidae) under different temperature conditions. - Environmental Entomology 41(4): 950-958. DOI: https://doi.org/10.1603/ EN11286

Bartlett, J.C., Convey, P., and Hayward, S.A. 2018. Life cycle and phenology of an Antarctic invader: the flightless chironomid midge, Eretmoptera murphyi. - Polar Biology 42:1-16. DOI: https://doi.org/10.1007/s00300-018-2403-5

Bartlett, J.C., Convey, P., and Hayward, S.A. 2020. Surviving the Antarctic winter - Life stage cold tolerance and ice entrapment survival in the invasive chironomid midge Eretmoptera murphyi. - Insects 11(3): 147. DOI: https://doi. org/10.3390/insects 11030147

Bell, G. 1982. The Masterpiece of Nature: The Evolution and Genetics of Sexuality. Univ. Calif. Press, Berkeley, 638 p.

Braegelman, S.D., 2016. Seasonality of some arctic Alaskan chironomids. Ph.D. Thesis, North Dakota State University, Fargo, North Dakota. 80 p.

Butler, M.G. 1980. Emergence phenologies of 
some arctic Alaskan Chironomidae. In Murray, D.A. (Ed.) Chironomidae Ecology, Systematics Cytology and Physiology, 1 st Ed. Elsevier Ltd., pp. 307-314.

Butler, M.G. 1982. A 7-year life cycle for two Chironomus species in arctic Alaskan tundra ponds (Diptera: Chironomidae). - Canadian Journal of Zoology 60(1): 58-70. DOI: https:// doi.org/10.1139/z82-008

Butler, M.G., and Braegelman, S. D. 2018. Preemergence growth and development in the arctic midge Trichotanypus alaskensis Brundin. - Journal of Limnology. DOI: https://doi. org/10.4081/jlimnol.2018.1836

Carew, M., Gagliardi, B., and Hoffmann, A.A. 2013. Mitochondrial DNA suggests a single maternal origin for the widespread triploid parthenogenetic pest species, Paratanytarsus grimmii, but microsatellite variation shows local endemism. - Insect Science 20(3), 345357. DOI: https://doi.org/10.1111/j.17447917.2012.01564.x

Crafford, J.E. 1971. A case study of an alien invertebrate (Limnophyes pusillus, Diptera, Chironomidae) introduced on Marion Island: selective advantages. - South African Journal of Antarctic Research Vol 4.

Cranston, P.S., Hardy, N.B., and Morse, G. E. 2012. A dated molecular phylogeny for the Chironomidae (Diptera). - Systematic Entomology 37(1), 172-188. DOI: https://doi. org/10.1111/j.1365-3113.2011.00603.x

Darlington, C.D. (1946). Evolution of genetic systems. Cambridge University Press: London.

Delettre, Y.R., Frenot, Y., Vernon, P., and Chown, S.L. 2003. First record of Telmatogeton sp. (Diptera: Chironomidae) at Heard Island. - $\mathrm{PO}_{\mathrm{O}}$ lar Biology 26(6), 423-426. DOI: https://doi. org/10.1007/s00300-003-0502-3

Donato, M., and Paggi, A.C. 2008. Polypedilum parthenogeneticum (Diptera: Chironomidae): a new parthenogenetic species from Eryngium L. (Apiaceae) phytotelmata. - Aquatic Insects 30(1), 51-60. DOI: https://doi. org/10.1080/01650420701829633

Edward, D.H., and Colless, D.H. 1968. Some Australian parthenogenetic Chironomidae (Diptera). - Australian Journal of Entomology 7(2), 158-162. DOI: https://doi. org/10.1111/j.1440-6055.1968.tb00724.x

Edwards, F.W. 1919. XX. Some parthenoge- netic Chironomidae. - Journal of Natural History 3(14), 222-228. DOI: https://doi. org/10.1080/00222931908673815

Ekrem, T., Stur, E. and Hebert, P.D.N. 2010. Females do count: Documenting Chironomidae (Diptera) species diversity using DNA barcoding. - Organisms Diversity \& Evolution 10,397-408. DOI: https://doi.org/10.1007/ s13127-010-0034-y

Ferrington, L.C. 2007. Global diversity of non-biting midges (Chironomidae; Insecta-Diptera) in freshwater. - Hydrobiologia 595, 447 (2008). DOI: https://doi.org/10.1007/s10750-0079130-1

Forsyth, D.J. 1971. Some New Zealand Chironomidae (Diptera). - Journal of the Royal Society of New Zealand 1(2), 113-144. DOI: https:// doi.org/10.1080/03036758.1971.10419345

Ghiselin, M.T. 1974. The Economy of Nature and the Evolution of Sex. Univ. Calif. Press, Berkeley, $346 \mathrm{p}$.

Gokhman, V.E., and Kuznetsova, V.G. 2017. Parthenogenesis in Hexapoda: holometabolous insects. - Journal of Zoological Systematics and Evolutionary Research, 56(1), 23-34. DOI: https://doi.org/10.1111/jzs.12183

Grimm, O.von. 1870. Die ungeschlechtliche Fortpflanzung einer Chironomus-Art und deren Entwicklung aus dem unbefruchteten Ei. Zap. imp. Akad, Nauk. 7: Serie 15: 1-24.

Grodhaus, G. 1971. Sporadic parthenogenesis in three species of Chironomus (Diptera). - The Canadian Entomologist 103(3), 338-340. DOI: https://doi.org/10.4039/Ent103338-3

Intergovernmental Panel on Climate Change (IPCC). Fifth Assessment Report 2014.

International Symposium on Chironomidae (ISC) 2017. Trento, Italy.

Lackmann, A.R., and Butler, M.G. 2018. Breaking the rule: Five larval instars in the podonomine midge Trichotanypus alaskensis Brundin from Barrow, Alaska. - Journal of Limnology 77(s1), 31-39. DOI: https://doi.org/10.4081/ jlimnol.2018.1758

Langton, P.H. 1998. Micropsectra silvesterae n. $\mathrm{sp}$. and Tanytarsus heliomesonyctios n. sp. (Diptera: Chironomidae), two parthenogenetic species from Ellesmere Island, Arctic Canada. - Journal of the Kansas Entomological Society 208-215. 
Liljedahl, A.K., Hinzman, L.D., and Schulla, J. 2012. Ice-wedge polygon type controls lowgradient watershed-scale hydrology. In Proceedings of the Tenth International Conference on Permafrost Vol 1, 231-236. The Northern Publisher: Salekhard, Russia.

Liljedahl, A.K., Boike, J., Daanen, R.P., Fedorov, A.N., Frost, G.V., Grosse, G., Hinzman, L.D., Iijma, Y., Jorgenson, J.C., Matveyeva, N., Necsoiu, M., Raynolds, M.K., Romanovsky, V.E., Schulla, J., Tape, K.D., Walker, D.A., Wilson, C.J., Yabuki H., and Zona, D., 2016. Pan-Arctic ice-wedge degradation in warming permafrost and its influence on tundra hydrology. - Nature Geoscience, 9(4), 312-318. DOI: https://doi. org/10.1038/ngeo2674

Lindeberg, B. 1958. A parthenogenetic race of Monotanytarsus boreoalpinus Th. (Dipt., Chironomidae) from Finland. - Ann. Entomol. Fennici 24, 35-38.

Lindeberg, B. 1971. Parthenogenetic strains and unbalanced sex ratios in Tanytarsini (Diptera, Chironomidae). - Annales Zoologici Fennici 310-317.

Lougheed, V.L., Butler, M.G., McEwen, D.C., and Hobbie, J.E. 2011. Changes in tundra pond limnology: Re-sampling Alaskan ponds after 40 years. - Ambio 40(6), 589-599. DOI: https:// doi.org/10.1007/s13280-011-0165-1

Lynch, M. 1984. Destabilizing hybridization, general-purpose genotypes and geographic parthenogenesis. - The Quarterly Review of Biology, 59(3), 257-290. DOI: https://doi. org/10.1086/413902

Mayr, E. 1970. Populations, Species, and Evolution. Belknap Press, Cambridge.

McEwen, D.C., and Butler, M.G. 2018. GrowingSeason Temperature Change across Four Decades in an Arctic Tundra Pond. - Arctic 71(3), 281-291. DOI: https://doi.org/10.14430/arc$\underline{\text { tic4730 }}$

Oliver, D.R., and Danks, H.V. 1972. Sex ratios of some high arctic Chironomidae (Diptera). - The Canadian Entomologist 104(9), 1413-1417.
Orel, O.V., and Semenchenko, A.A. 2019. Morphological description and DNA barcodes of adult males of Tanytarsus heliomesonyctios Langton, 1999 (Diptera, Chironomidae) in northeast of Russia. - Zootaxa, 4686(1), 119-126. DOI: https://doi.org/10.11646/zootaxa.4686.1.6

Porter, D.L., and Martin, J. 2011. Cytogenetics of a parthenogenetic Arctic species of Micropsectra (Diptera, Chironomidae). - Comparative Cytogenetics 5(4), 315-328. DOI: https://doi. org/10.3897/CompCytogen.v5i4.1356

Siri, A., and Donato, M. 2014. Monopelopia caraguata (Chironomidae: Tanypodinae: Pentaneurini) and Phytotelmatocladius delarosai (Chironomidae: Orthocladiinae): two phytotelmatous chironomids distributed from Florida to Argentina. - Florida Entomologist 97(3), 1226-1231. DOI: https://doi. org/10.1653/024.097.0330

Smith, J.M. 1978. The evolution of sex (No. 574.1 S5). Cambridge: Cambridge University Press, $236 \mathrm{p}$.

Stur, E., and Ekrem, T. 2020. The Chironomidae (Diptera) of Svalbard and Jan Mayen. - Insects, 11(3), 183. DOI: https://doi.org/10.3390/ insects 11030183

Suomalainen, E. 1962. Significance of parthenogenesis in the evolution of insects. - Annual Review of Entomology 7(1), 349366. DOI: https://doi.org/10.1146/annurev. en.07.010162.002025

Thienemann, A. 1954. Chironomus. Leben, Verbreitung und Wirtschaftliche Bedeutung der Chironomiden. Binnengewiisser 20: 1-834.

Vandel, A. 1928. La parthénogenèse géographique. Contribution à l'étude biologique et cytologique de la parthénogenèse naturelle. Bull. Biol. France Belg. 62, 164-281.

Wiederholm, T. 1986. Chironomidae of the Holarctic region Part 2. Pupae. Entomologica Scandinavica Supplement, 482p.

Article submitted 3. March 2020, accepted by Torbjørn Ekrem 25. August 2020, published 13. September 2020. 